\title{
Exploring the physiological and agronomic response of Armoracia rusticana grown in rainfed Mediterranean conditions
}

\author{
Anna Rita Rivelli, Susanna De Maria \\ School of Agricultural, Forest, Food and Environmental Sciences, University of Basilicata, Potenza, Italy
}

\begin{abstract}
Horseradish (Armoracia rusticana) is a perennial plant, belonging to the Brassicaceae family, whose roots are widely used as a cooking spice and flavouring agent across the world and has recently acquired considerable scientific interest due to the richness of phytochemicals. Aim of the study was to explore water relations in plants grown in pots and subject to severe stress conditions and gas exchange, plant growth, and agronomic characteristics of two horseradish accessions grown in open field under rainfed Mediterranean conditions. Total and osmotic leaf water potential were significantly reduced by water stress to a similar extent at predawn and middle day. The carbon isotope composition $\left(\delta^{13} \mathrm{C}\right)$ (on average -34.2 and $-28.9 \%$ in leaves and roots, respectively) resulted statistically different among water stress treatments in leaves collected at middle day. In open field, during the vegetative development, plants regulate the foliage expansion depending on rainfall distribution and temperature. When the dry period occurs, plants get rid of several mature leaves that dry completely, and might develop new leaves in the next period, when the air-cools and rainfall increases. During the dry period, horseradish optimised gas exchange during the day by increasing the net $\mathrm{CO}_{2}$ assimilation rate during the early morning (up to $31 \mu \mathrm{mol} \mathrm{CO}{ }_{2}^{-2} \mathrm{~s}^{-1}$, on average),
\end{abstract}

Correspondence: Anna Rita Rivelli, School of Agricultural, Forest, Food and Environmental Sciences, University of Basilicata, via dell'Ateneo Lucano 10, 85100 Potenza, Italy.

Tel.: +39.0971.205382 - Fax: +39.0971.205378.

E-mail: annarita.rivelli@unibas.it

Key words: Horseradish; Brassicaceae; gas exchange; leaf water potential; plant growth.

Acknowledgements: the authors are grateful to Giuseppe Mercurio and Salvatore Saluzzi for the technical assistance in open field and laboratory.

Received for publication: 1 April 2019.

Revision received: 28 June 2019.

Accepted for publication: 1 July 2019.

(C) Copyright: the Author(s), 2019

Licensee PAGEPress, Italy

Italian Journal of Agronomy 2019; 14:1445

doi:10.4081/ija.2019.1445

This article is distributed under the terms of the Creative Commons Attribution Noncommercial License (by-nc 4.0) which permits any noncommercial use, distribution, and reproduction in any medium, provided the original author(s) and source are credited. when the sunlight intensity and the air temperature conditions are more favourable. The species, which rely on an annual rainfall of about $680 \mathrm{~mm}$, produced about 11.5 and $24.3 \mathrm{t} / \mathrm{ha}$ of roots from one- and two-year-old plantations, respectively. Regardless of accessions, close relationships were found between the number of leaves and root weight $\left(\mathrm{R}^{2}=0.88\right.$ and $\left.\mathrm{P} \leq 0.01\right)$ and diameter $\left(\mathrm{R}^{2}=0.82\right.$ and $\left.\mathrm{P} \leq 0.01\right)$. The results advise the importance to know the physiology and agronomic characteristics of horseradish to purposefully apply agronomic practices and strategies to maximise benefits for production and root quality.

\section{Introduction}

Horseradish (Armoracia rusticana P. Gaertner, B. Meyer \& Scherbius), a species belonging to the Brassicaceae family, is a perennial rhizomatous plant with big oblong-ovate and long-petioled leaves and a large root system characterised by a white, cylindrical or tapering main root with several thin lateral roots (Courter and Rhodes, 1969; Sampliner and Miller, 2009; Shehata et al., 2009). Horseradish is mostly appreciated for the aromatic and spicy roots around the world, and it is mainly cultivated in Russia (about 5000 ha), Northeast Europe (particularly in Hungary with 1200 ha), Germany, Latvia, Ukraine, and North America (about 3500 ha in USA) (Filipović et al., 2015), mostly in Illinois where the International horseradish festival is celebrated annually. Currently, the scientific interest on the species has been increasing due to the richness of phytochemicals, which are tested for innovative applications in various sectors: from the medical and pharmaceutical fields (e.g., nasal and sinus dysfunction, urinary antiseptic drug, cancer protection) to the food industry (e.g., natural preservatives against bacteria and fish oomycete pathogens, cheaper substitute of wasabi) (as reviewed by Nguyen et al., 2013; Wedelsbäck Bladh, 2014). Indeed, the tissues of horseradish are abundant in horseradish peroxidase, an enzyme commonly used as a component of clinical diagnostic kits, in medical research and neuroanatomy, and in targeted cancer therapy (Veitch, 2004). Moreover, the plant is also very rich in glucosinolates (GLS), the main source of anticarcinogenic activity in Brassica vegetables. In studies performing comprehensive analysis on the identification and quantification of GLS in leaves and roots of horseradish, the species turned out to produce more GLS than other Brassicaceae (Agneta et al., 2014a), and in large amounts (Ciska et al., 2017; Rivelli et al., 2016b). Both, the above- and below-ground tissues contained high quantities of aliphatic GLS, with sinigrin that is the major GLS in horseradish (De Maria et al., 2016). Moreover, Bell et al. (2018) have shown a detailed characterisation of the commonly reported GLS and their hydrolysis products, particularly isothiocyanates and also sulphur-containing volatile compounds, and their associated tastes, aromas and flavour perceptions for several Brassicaceae species including horseradish. In addition, 
Kroener and Buettner (2018) found that six different horseradish accessions show differences in their aroma profile even when grown under equal conditions. Furthermore, a surprising amount of vitamin $\mathrm{C}$ is also reported for leaves and roots of horseradish (Rivelli et al., 2017), total phenols and flavonoids (Calabrone et al., 2015). In tandem with phytochemicals and secondary metabolite characterisation in horseradish, there is a growing need to delve into agronomic studies, of which scarce information is available in literature. Still very little is published about the amongaccession genetic diversity of the propagation material that nowadays is cultivated, the physiology of the species and the agronomic management. Numerous reviews and articles have been published on horseradish in the last few years; in some there are detailed ethnobotanical and ethnopharmacological data, and local as well as traditional uses as food and medicinal plant in several countries, as in Hungary, Romania and Albania (Nguyen et al., 2013; Papp et al., 2018; Stillo et al., 2018), Southern Italy (Sarli et al., 2012; Agneta et al., 2013; Guarrera and Savo, 2016), Nordic countries (Wedelsbäch and Olsson, 2011) and in native areas of Eastern Europe and Siberian Russia (Sampliner and Miller, 2009). While in other studies, the authors focus on GLS and their breakdown products potentially usable in innovative sectors thanks to their insecticidal (Chowański et al., 2018), herbicidal and antimicrobial activities (Vig et al., 2009; Saladino et al., 2016; Petrović et al., 2017), cancer chemoprotective properties (Sayeed et al., 2017) and human health. In the face of such multidisciplinary interest, very few studies have been published on agronomic practices and management of the crop in open fields, and most of them are referred almost exclusively to fertilisation and harvesting. Perlaki and Djurovka (2009), comparing organic and mineral fertilisers, recorded the highest total yield and the greatest main root weight using farmyard manure (40 t/ha) and mineral fertiliser (600 kg/ha). Filipović et al. (2015) showed a positive gross margin for organic horseradish, produced in Serbian metropolitan areas, by using the calculation of standard gross margin. Besides root yield increases, Rivelli et al. (2016a, 2016b) found a great increase of glucosinulates content, particularly sinigrin, in both roots and leaves, by adding nitrogen and sulphur fertilisers and by harvesting the roots of one year old during late winter for horseradish grown in a warm to temperate Mediterranean environment. According to Björkman et al. (2011), the production and phytochemicals content and profile of brassicaceous crops can be significantly affected by several factors, including plant species and cultivar, agronomic conditions (developmental stage, plant organ, plant density, fertilisation, $\mathrm{pH}$ ), season, water availability and climatic factors (mainly light and temperature). The knowledge of physiology and the agronomic characterisation of the species are useful and necessary basic issues to improve many aspects of the development and crop management in order to maximise benefits for production, root quality, phytochemicals content and nutritional value. This is especially evident for niche agriculture and organic farming, which produces healthy food and preserves natural resources (Filipović et al., 2015). In this context, the objectives of this study were to evaluate the plant growth, physiological behaviour and the agronomic characteristics of two horseradish accessions grown in rain fed Mediterranean conditions.

\section{Materials and methods}

\section{Experimental design in open field}

The experiment was carried out in two years (2014/15 and
2015/16) in Potenza (Southern Italy, 40³8’ N - 15²4' E, 819 m a.s.1.) on soil with $36.1 \%$ sand, $29 \%$ silt, $35 \%$ clay, $1.25 \mathrm{~kg} / \mathrm{dm}^{3}$ bulk density, $7.2 \mathrm{pH}$ in water, $0.14 \mathrm{mS} / \mathrm{cm}$ electrical conductivity (EC), and soil moisture content of $32.3 \%$ at field capacity and $13 \%$ at wilting point (obtained in the Richards chambers at -0.03 and 1.5 $\mathrm{MPa}$, respectively). The climatic conditions during the experiment were characterised by an annual rainfall of $693 \mathrm{~mm}$ and 671 $\mathrm{mm}$ in 2014 and 2015, respectively, versus $588 \mathrm{~mm}$ as a long-term average (1980-2010). The rainiest period went from January to March (210 and $271 \mathrm{~mm} v s 157 \mathrm{~mm}$ long-term mean value) while the driest conditions occurred from July to August (36.1 and 48.2 $\mathrm{mm}$ vs $66 \mathrm{~mm}$ long-term mean value). In both years, mean temperatures ranged, on average, from 6.9 (Jan-Feb) to 23 (Jul) and $8.1^{\circ} \mathrm{C}$ (Dec), against $3.7,20.5$ and $4.9^{\circ} \mathrm{C}$, respectively, as long-term average. Two selected accessions of $A$. rusticana, collected from local nurseries in Corleto Perticara $\left(40^{\circ} 23^{\prime} \mathrm{N}-16^{\circ} 03^{\prime} \mathrm{E}, 749 \mathrm{~m}\right.$ a.s.1.) and Montemurro ( $40^{\circ} 18^{\prime} \mathrm{N}$; $15^{\circ} 59^{\prime} \mathrm{E}, 723 \mathrm{~m}$ a.s.1.) municipalities of the Potenza Province, henceforth referred to as COR and MON, respectively, were tested. On March 31, 2014, root cuttings (approximately $18 \mathrm{~cm}$ in length and $1.0 \mathrm{~cm}$ in diameter) were transplanted in single rows in open field, previously ploughed and fertilised with $100 \mathrm{~kg} \mathrm{~N} \mathrm{ha}^{-1}$ and $15 \mathrm{~kg} \mathrm{~S} \mathrm{ha}^{-1}$. The experimental design was a randomised complete block with three replicates; the plots were $8 \mathrm{~m}$ long with a row spacing of $60 \mathrm{~cm}$ between rows and $40 \mathrm{~cm}$ within the row, and a crop density of 4 plant $\mathrm{m}^{-2}$. Plant protection and weed control were carried out according to local practices and weather conditions.

\section{Experimental design in pots}

In order to investigate water relations in plant, 21 root cuttings (10 $\mathrm{cm}$ in length and $1 \mathrm{~cm}$ in diameter) were transplanted singly into $13 \times 13 \times 20 \mathrm{~cm}$ pots filled with $2.2 \mathrm{~kg}$ of soil collected from the first layer of $30 \mathrm{~cm}$ in open field, and maintained wet until leaf emergence. The soil surface was covered with a 3-cm layer of polythene beads to prevent soil evaporation. After two weeks, the 21 pots were separated in three groups of seven replicates each and subject to different levels of water stress by re-establishing, respectively, the 100 (V100 as control), 40\% (V40) and 10\% (V10) of the field capacity, until the end of the experiment when plants were harvested by the end of June 2014, about 80 days after transplanting (DAT).

\section{Physiological parameters measured in plants grown in pots}

Before to cut the plants grown in pots, leaf water potential $(\psi)$ was measured at the end of the experiment ( 80 DAT) on the youngest fully expanded leaves of seven plants for treatment at predawn (for plants maintained overnight in the dark) and midday by using the Scholander pressure chamber (PMS model 1000, Corvallis, OR). Leaf samples excluding the petiole were placed in microtubes, frozen immediately in liquid nitrogen and stored at $20^{\circ} \mathrm{C}$. The sap was then collected by crushing the thawed tissues with a mechanical press at constant pressure and centrifuged in Eppendorf for $2 \mathrm{~min}$ at $12,000 \mathrm{rpm}$. Osmolarity of the sap was measured with a Micro-Digital Osmometer type 6, freezing point depression osmometer (Roebling, Berlin, Germany). Osmotic potential $\left(\psi_{\pi}\right)$ was calculated from osmolarity by the Van't Hoff equation. Turgor $\left(\psi_{\mathrm{p}}\right)$ was estimated as the difference between $\psi$ and $\psi_{\pi}$. Relative water content (RWC) was also determined using $1-\mathrm{cm}^{2}$ segments of leaf tissue. Leaf portions were weighted immediately after sampling to record a fresh weight (FW). Turgid weight (TW) was recorded after tissue portions were floated in distilled water for about $6 \mathrm{~h}$ to reach its maximum, and then blotted to 
remove adhering surface water. Dry weight (DW) was measured after drying at $75^{\circ} \mathrm{C}$ for 2 days. RWC was calculated as (FWDW $/($ TW-DW $)$. Afterwards, plants were harvested and weighted for fresh weight (FW) and dry matter weight (DW) after dried the leaves and roots in a ventilated oven at $75^{\circ} \mathrm{C}$ until steady weight. Then, using $0.6-0.8 \mathrm{mg}$ of leaves and roots oven-dried and finely ground, stable $\mathrm{C}$ isotope composition $\left(\delta^{13} \mathrm{C}\right)$ was measured at the Stable Isotope Core (Washington State University) using a continuous flow isotope ratio mass spectrometer (Delta PlusXP, Termofinnigan, Bremer). $\delta^{13} \mathrm{C}$ was expressed in delta notation (\%o) relative to the Pee-Dee Belemnite, the international standard.

\section{Physiological parameters and plant growth analysis in open field}

Gas exchange parameters (net $\mathrm{CO}_{2}$ assimilation rate $-A$; stomatal conductance - $g s$; sub-stomatal $\mathrm{CO}_{2}$ concentration $-\mathrm{Ci}$; transpiration $-T$ ) were recorded by using a LI-6400 portable gas

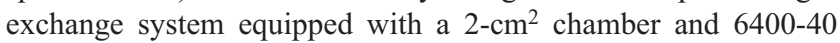
LED light source (Li-COR, Lincoln, NE, USA), operating at 380ppm ambient $\mathrm{CO}_{2}$ concentration. The measurements were taken in open field from 8:00 to 19:00 h (solar time), approximately every two hours, using the same youngest fully expanded leaf of 6 plants of COR and MON accessions, at stage S1 (during the vegetative development of the plants in the first year of the experiment, 2014/2015). On the same leaves used for gas exchange measurements, samples of fresh leaf tissue were taken for chlorophyll determination at 11:00 $\mathrm{h}$ and 17:00 h, ground with a glass homogenizer in $2 \mathrm{~mL}$ of $80 \%$ acetone $(\mathrm{v} / \mathrm{v})$ and centrifuged at $12.000 \mathrm{rpm}$ for $2 \mathrm{~min}$. Chlorophyll content $(\mu \mathrm{g} / \mathrm{mL})$ was calculated according to Porra et al. (1989).

Throughout the whole growing cycle of the first year (from leaf emergence by the end of April 2014 to root harvesting in January 2015), the maximum length of the lamina (L, from lamina tip to the point of petiole intersection along the midrib) and midlength width (W) of all the leaves of 4 plants for each accession were measured (to the nearest $0.1 \mathrm{~cm}$ with a simple ruler) every week. These parameters were subsequently fitted in the regression linear models $\mathrm{LA}=0.71 \mathrm{LW}-0.27$ and $\mathrm{LA}=0.76 \mathrm{LW}-3.22$ for COR and MON, respectively, to estimate the leaf area (LA), according to De Maria et al. (2018). In addition, during both growing cycles (2014/15 and 2015/16), 4 plants for each accession were collected in three phenological stages: (S1) during the vegetative development of the plants (July), (S2) at the beginning of leaf senescence (September), and (S3) at root harvesting (January). At each data sampling, the height (from the soil line to the top of the longest leaf) for each accession was measured, then plants were manually dug out, cleaned with tap water, dried with paper towels and divided into above- and below-ground portions. The aboveground portion was further separated into green, senescent and dry leaves (at S1 and S2 stages) or in dry and young leaves wrapped in a rosette (at S3 stage). All types of leaves were counted and weighted to determine FW. The below-ground portion was separated into main root (including the crown with buds and/or rosette leaves) and side roots. Thereafter, based on the descriptor list of Petřiková et al. (1998) and UPOV guidelines (2001), selected morphometric parameters were detected: diameter at the top and diameter at the base of the main root, number of side roots (with diameters larger than and less than $0.5 \mathrm{~cm}$ ) and FW. Root surface texture (glabrous or wrinkled), colour and shape in longitudinal section were also recorded. Finally, to measure the DW, leaves and roots were dried in a ventilated oven at $70^{\circ} \mathrm{C}$ until steady weight.

Statistical analysis was performed by using M-STAT software (version 2.00, East Lansing, USA). Variable were tested with ANOVA followed by Duncan test to separate the means. Significance levels were expressed as ${ }^{*} \mathrm{P} \leq 0.05 ; * * \mathrm{P} \leq 0.01$ and $* * * \mathrm{P} \leq 0.001$.

\section{Results and discussion}

\section{Water relations and carbon isotope composition}

Results from water relations and carbon isotope composition $\left(\delta^{13} \mathrm{C}\right)$ of plants grown in pots are reported in Figure 1 and Table 1. For all parameters analysed, since no significant differences were found between the two accessions of horseradish, the average values are considered below. The RWC was steady with time in control plants (V100) through the experimental period (95 and 93\% at predawn and middle day, respectively) and it slightly decreased in the most stressed treatment (V10) that showed, on average, values of 90 and $88 \%$, respectively at predawn and in middle day (data not shown). Total leaf water potential $(\psi)$ and osmotic potential $\left(\psi_{\pi}\right)$ were significantly reduced by water stress to a similar extent at predawn and middle day (Figure 1). $\psi$ and $\psi_{\pi}$ measured at predawn, respectively decreased passing from -0.15 and -0.89 $\mathrm{MPa}$ in the control treatment (V100) to -0.93 and $-1.13 \mathrm{MPa}$ in the most stressed treatment (V10), while in middle day they decreased passing from -0.42 and -0.95 to -1.30 and $-1.56 \mathrm{MPa}$ in $\mathrm{V} 100$ and V10 treatments, respectively. At the end of the experiment (Figure 1), differences of 0.14 and $0.54 \mathrm{MPa}$ (at predawn) and 0.16 and $0.33 \mathrm{MPa}$ (in middle day) of the calculated turgor $\left(\psi_{p}\right)$ were observed in control plants with respect to stressed plants, V50 and V10 treatments, respectively. The carbon isotope composition $\left(\delta^{13} \mathrm{C}\right)$ of leaves and roots was on overage -34.2 and $-28.9 \%$, respectively; it was significantly lower in the leaves of the most stressed treatment (V10) collected at middle day (Table 1), reflecting a physiological response to water stress. As a consequence of the different water supply, the growth of the plants was affected in stressed treatments compared to the control (V100); after 65 days of water stress, the leaf area and final biomass production were

Table $1 . \delta^{13} \mathrm{C}(\%)$ of horseradish leaves collected at predawn and middle day and roots. Values show means \pm S.E. (n=7) for control (V100) and stressed plants (V40 and V10).

\begin{tabular}{lccc} 
Treatment & Predawn & Leaves & Roots \\
V100 & $-34.9 \pm 0.38$ & $-35.1 \pm 0.13^{\mathrm{A}}$ & $-28.5 \pm 0.21$ \\
V40 & $-34.0 \pm 0.59$ & $-34.5 \pm 0.48^{\mathrm{AB}}$ & $-29.0 \pm 0.41$ \\
\hline V10 & $-33.5 \pm 0.68$ & $-33.7 \pm 0.42^{\mathrm{B}}$ & $-29.2 \pm 0.36$ \\
F probability & n.s. & $*$ & n.s. \\
\hline Significant levels are expressed as *P $\leq 0.05$; n.s. not significant.
\end{tabular}

Significant levels are expressed as $* \mathrm{P} \leq 0.05 ;$ n.s. not significant. 
reduced, respectively, by $46.2 \%$ and $44.1 \%$ (38.7\% roots and $45.4 \%$ leaves) in V50 treatment and by $56.8 \%$ and $56.1 \%(47.5 \%$ roots and $59.3 \%$ leaves) in V10 treatment with respect to the unstressed control (V100). According to Martínez-Ballesta et al. (2013), drought is expected to reduce vegetative growth with the subsequent increase of secondary metabolites at the expense of primary metabolism. The effects of water stress and dry conditions on the variations of phytochemicals and secondary metabolism in plants have been intensely investigated in a number of Brassicaceae species (as summarised by Björkman et al., 2011; and Martínenez-Ballesta et al., 2013). According to the authors, when plants are stressed, secondary metabolism may increase resulting in a higher glucosinulates content with respect to the plants grown under favourable conditions. However, it is useful to report, that in the face of the glucosinulates accumulation as part of plant response to stress through the process of osmotic adjustment, comparing several brassicaceae species, contradictory results have been reported by Martínenez-Ballesta et al. (2013); according to the authors the accumulation of each individual glucosinulate may vary depending on species, intensity and duration of the stress and plant developmental stage. Considering horseradish, it is generally claimed that the species thrives with adequate moisture in the soil, and that to ensure greater root yields, supplemental irrigation may be applied during the dry months.
Unfortunately, very little is published on water stress related to growth, yield and glucosinolates profile and content in horseradish and even less data are available on water requirement and irrigation scheduling. Our results highlight that horseradish, when subjected to severe water stress, shows a considerable reduction of plant development and growth of both leaves and roots.

\section{Gas exchange, growth and agronomic characteristics of the above- and below-ground tissues}

Results from gas exchange measurements in plants grown in open field during the first growing cycle are reported in Figure 2. For all parameters analysed, horseradish accessions did not significantly differ with each other. The $\mathrm{CO}_{2}$ assimilation rate (A) increased from 8:00 $\mathrm{h}$ to 11:00 $\mathrm{h}$ reaching the highest values during the early morning (from approximately 17 up to $31 \mu \mathrm{mol} \mathrm{CO} \mathrm{Cm}^{-2} \mathrm{~s}^{-1}$, on average). It then starts to decline around 13:00 $\mathrm{h}$ reaching a lower value of $9 \mu \mathrm{mol} \mathrm{CO} \mathrm{Cm}^{-2} \mathrm{~s}^{-1}$ at 19:00 h. A similar trend was observed for $g s$ that was, on average, 0.56 and $0.32 \mathrm{~mol} \mathrm{H}_{2} \mathrm{O} \mathrm{m}^{-2} \mathrm{~s}^{-1}$ during the morning and afternoon, respectively. The intercellular $\mathrm{CO}_{2}$ concentration $(\mathrm{Ci})$ started to decrease from $300 \mu \mathrm{mol} \mathrm{CO}_{2}$ $\mathrm{mol}^{-1}$ at 8:00 h down to 200 at 10:00 h until 16:00 h and increased again up to $280 \mu \mathrm{mol} \mathrm{CO} \mathrm{Col}^{-1}$ in late afternoon. Transpiration (T) showed a bell trend during the day with the two highest peaks
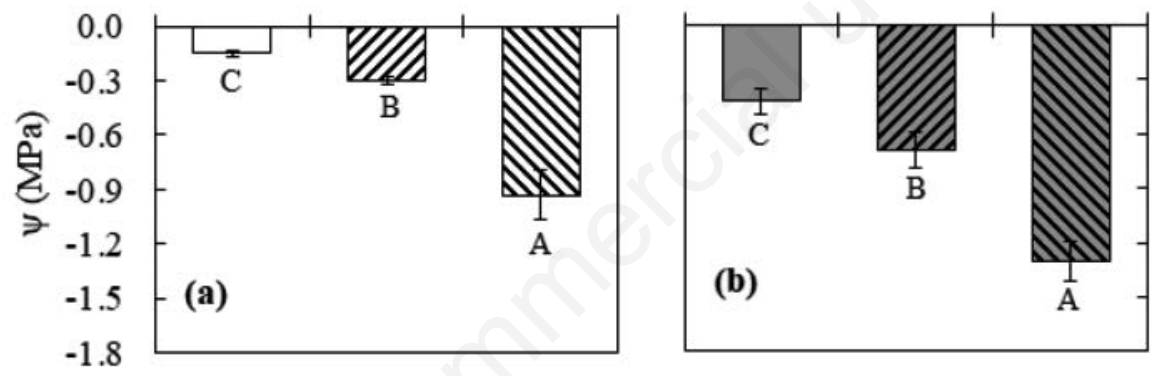

0.0

$-0.3$

$-0.6$

$-0.9$

$-1.2$

$-1.5$
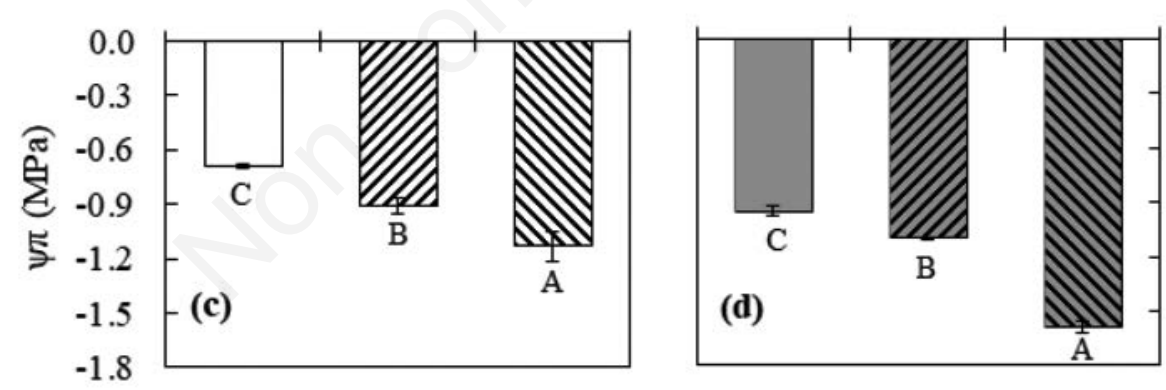

$-1.8$

0.0

$-0.3$

$-0.6$

$-0.9$

$-1.2$

$-1.5$
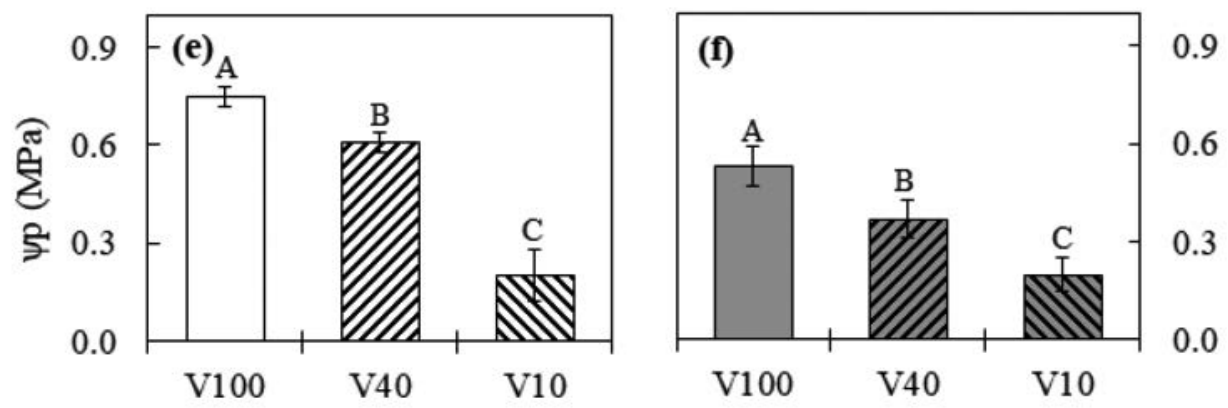

Figure 1. Total leaf water potential (a, b), osmotic potential (c, $d$ ) and turgor $(e, f)$ of the youngest fully expanded leaves of horseradish measured at predawn (white bars on the left) and middle day (gray bars on the right) at the end of the experiment ( 80 days after root transplanting). Values are means $(n=7) \pm$ s.e. In each graph, different uppercase letters over the bars indicate significant differences for $\mathbf{P} \leq \mathbf{0 . 0 5}$ according to Duncan's test. 
of about $14 \mathrm{mmol} \mathrm{H}_{2} \mathrm{O} \mathrm{m}^{-2} \mathrm{~s}^{-1}$ at 11:00 $\mathrm{h}$ and 16:00 h. Total chlorophyll concentrations measured at 11:00 and 17:00 h, as expected, were not different from each other; however, the MON accession showed a higher concentration in comparison to COR (average values of 19.7 and $17.8 \mu \mathrm{g} \mathrm{mL}^{-1}$, respectively) (data not shown). Gas exchange data associated with $\delta^{13} \mathrm{C}$ values suggest that horseradish, like other Brassicaceae, belongs to the $\mathrm{C}_{3}$ species, which generally show $\delta^{13} \mathrm{C}$ values lower than $-20 \%$. Based on our
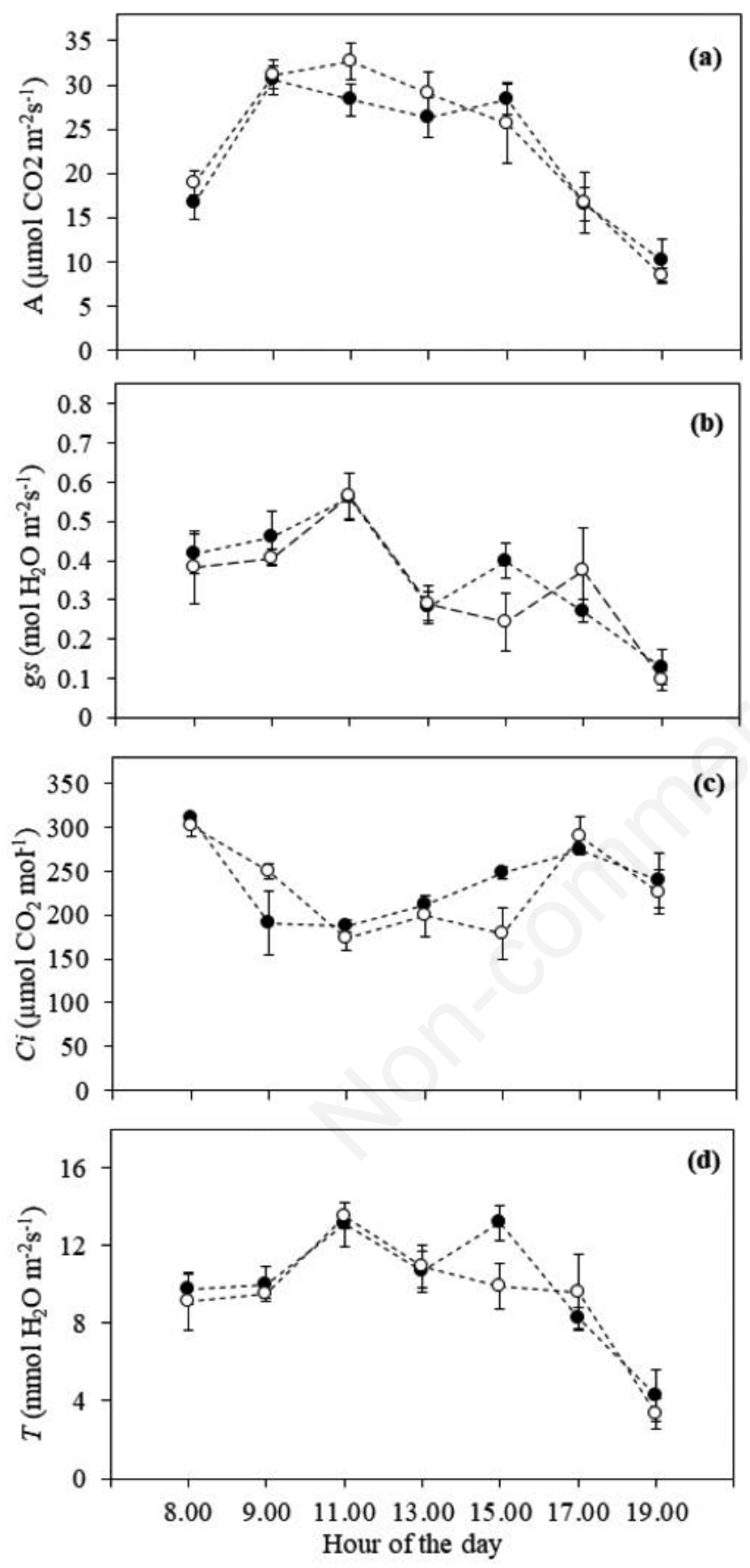

Figure 2. (A) Net $\mathrm{CO}_{2}$ assimilation rate (a), (gs) stomatal conductance (b), $(C i)$ sub-stomatal $\mathrm{CO}_{2}$ concentration $(c)$ and $(T)$ transpiration (d) of two horseradish accessions (COR and MON in black and white circles, respectively) measured from 8:00 a.m. to 19:00 p.m. during the stage of vegetative development. Values are means $(n=6) \pm s . e$. results, we hypothesize that when horseradish experiences drought, it optimises gas exchange during the day by increasing the net $\mathrm{CO}_{2}$ assimilation rate (up to $31 \mu \mathrm{mol} \mathrm{CO} \mathrm{CO}^{-2} \mathrm{~s}^{-1}$, on average) in the early morning, when the sunlight intensity and the air temperature conditions are more favourable. As observed in pots experiment it also lowers the leaf osmotic potential in severe water stress conditions, probably to adjust osmotically to maintain turgor and stomatal conductance. On the other hand, it is known that plants normally respond to abiotic stress with the accumulation of compatible osmolytes, hormone homeostasis and morphological changes in foliage and plant growth. The plant growth, expressed as green leaf area (LA, $\mathrm{cm}^{2}$ plant $^{-1}$ ) of COR and MON accessions cultivated under Mediterranean rainfed conditions, during 2014/15 and 2015/16, is reported in Figure 3. In both accessions, the leaf emergence occurred at 35 DAT, subsequently as temperatures rose, horseradish started to develop the foliage and the LA increased up to $6000 \mathrm{~cm}^{2}$ plant ${ }^{-1}$ during the vegetative development stage (120 DAT). During the following period, from July to August, which is usually the hottest and driest period $\left(22-25^{\circ} \mathrm{C}\right.$ air mean temperature and $36-48 \mathrm{~mm}$ of rainfall, see more details in materials and methods), the plants got rid of several mature and old leaves that dry completely (12 and $18 \%$ of total leaves in MON and COR, respectively) and continue to produce new leaves in the next period, when the air cools and rainfall increases (end of AugustSeptember). During this period, the horseradish plants reached the maximum LA, with MON accession that showed a higher value in comparison to $\operatorname{COR}\left(10,000\right.$ vs $8000 \mathrm{~cm}^{2}$ plant $^{-1}$, corresponding to 5 and 4 of leaf area index, LAI, in our field condition with 4 plants $\mathrm{m}^{-2}$ ). As autumn approached, the plants entered into senescence and the LA gradually decreased until late winter, when the foliage was completely dried and on the root crown new buds and rosette leaves were already formed. Horseradish is a perennial species, usually cultivated as an annual crop, planted at the beginning of the spring by root cuttings and harvested once the foliage has been killed by frost from late autumn to the end of winter (Sampliner and Miller, 2009; Shehata et al., 2009). If roots are not harvested and left in the field, they continue to grow, both in weight and in diameter (Rivelli et al., 2016b). In Mediterranean environments as spring approaches (towards the end of March and early April), the rosette leaves begin to develop and a new growing cycle begins,

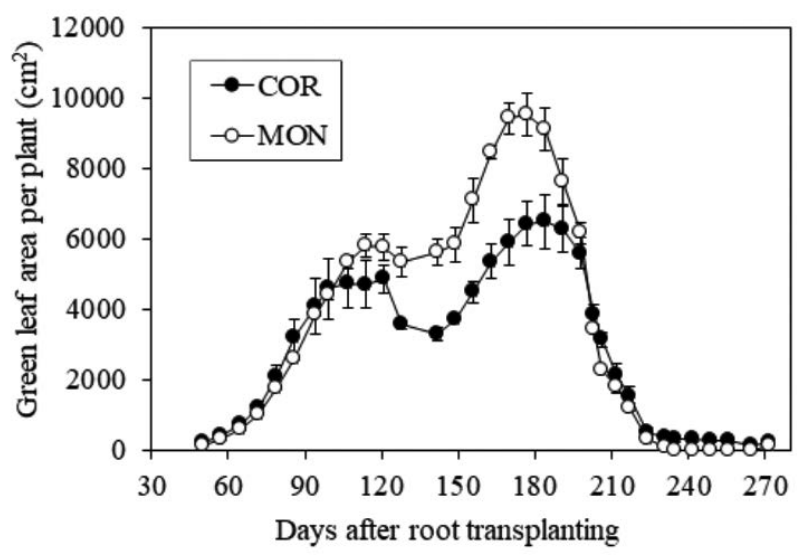

Figure 3. Green leaf area of two horseradish accessions (COR and MON in black and white circles, respectively) during the whole growing cycle, from root transplanting to root harvesting. Values are means $(n=4) \pm s . e$. 
with the development of almost double the foliage compared to the previous year, when root cuttings were transplanted. The doubling of the leaf surface from the first to the second growing season depends on the simultaneous enlargement of the root and the formation of multiple heads that are rounded knobs at or near the top of the root to which the leaves are attached (Rivelli et al., 2016b). Overall, during the growing season, plants regulate the expansion of the leaves and enlargement of the root depending on rainfall distribution and air temperatures. Our results, obtained in plants subjected to severe stress conditions in pot as well as in plants grown in the open field that have experienced a very dry summer, suggest that to avoid drastic reduction on plant growth, water should be applied to horseradish particularly during the dry period in the Mediterranean environments to not compromise quality and root production.

In addition to LA development, in Table 2 are summarised several agronomic characteristics of the two accessions (COR and $\mathrm{MON}$ ), referred both to the above-ground portion (fresh weight, number of leaves and plant height measured from the soil line to the top of the longest leaf) and below-ground portion (root weight and diameters, number of side roots), recorded at the stages of vegetative development (S1), leaf senescence (S2) and root harvesting (S3), throughout the growing cycles (2014/15 and 2015/16). Considering the above-ground portion, both accessions exhibited similar trends during the two growing cycles and resulted not significantly different from each other, except for leaf number (Table 2 ), while significant differences were found among the stages analysed in the two growing cycles. The FW and number of leaves increased from 340 g plant $^{-1}$ (on average) and 16 and 21 leaves for COR and MON, respectively, to $852 \mathrm{~g} \mathrm{plant}^{-1}$ and 55 and 82 leaves (with a maximum length of about $61 \mathrm{~cm}$ ) passing from $\mathrm{S} 1$ stage of the first growing cycle to the next. Subsequently, the plants lose $30 \%$ of the weight at stage S2, when the plant enters the senescence, reaching the lowest value of 286 g plant $^{-1}$ at stage S3, when
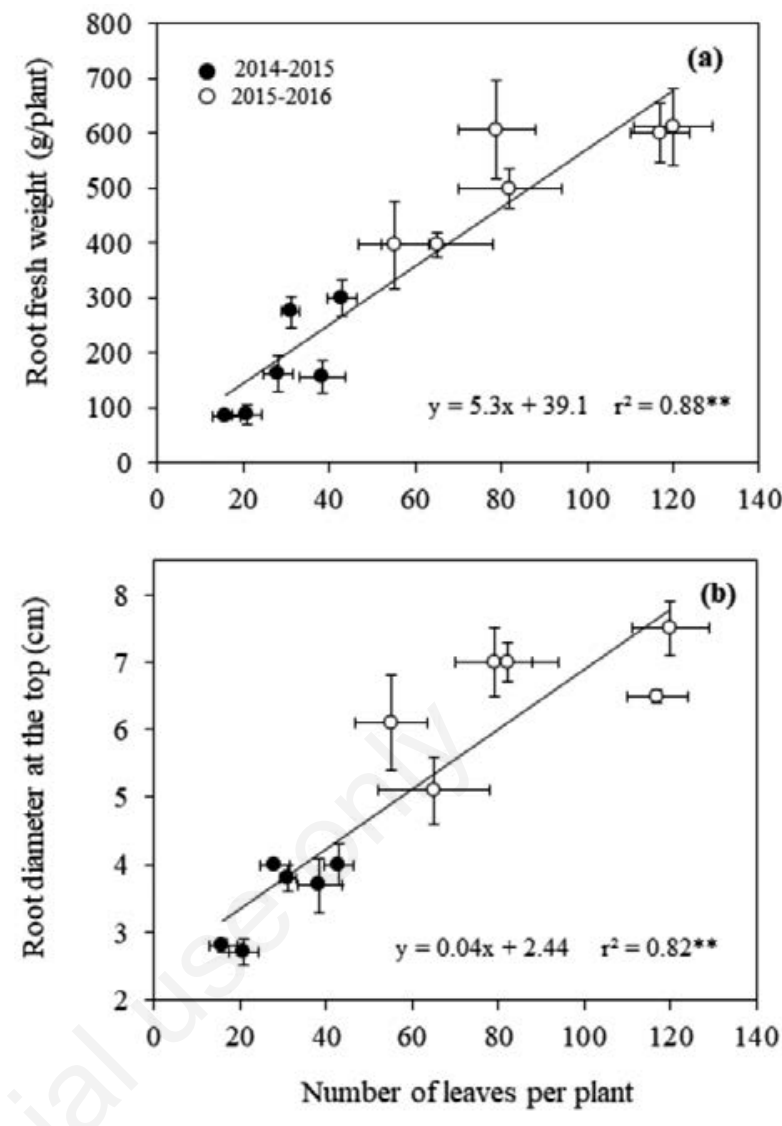

Figure 4. Relationships between number of leaves per plant and root fresh weight (a) and root diameter at the top (b). Values are means $(n=6) \pm$ s.e.

Table 2. Agronomic characteristics of leaves and roots of two horseradish accessions (COR and MON) evaluated during two growing seasons, at the stages of vegetative development of the plant (S1), beginning of leaf senescence (S2) and root harvesting (S3).

\begin{tabular}{|c|c|c|c|c|c|c|c|c|c|c|c|}
\hline \multirow{2}{*}{$\begin{array}{l}\text { Growing } \\
\text { season }\end{array}$} & \multirow[t]{2}{*}{ Stage } & \multirow[t]{2}{*}{ Accession } & \multirow{2}{*}{\multicolumn{2}{|c|}{$\begin{array}{l}\text { Leaves } \\
\text { Leaf } \\
\text { number } \\
\text { (n/plant) }\end{array}$}} & \multirow[b]{2}{*}{$\begin{array}{l}\text { Maximum } \\
\text { leaf } \\
\text { length } \\
(\mathrm{cm})\end{array}$} & \multirow[b]{2}{*}{$\begin{array}{l}\text { Fresh } \\
\text { weight } \\
\text { (g/plant) }\end{array}$} & \multirow[b]{2}{*}{$\begin{array}{l}\text { Diameter } \\
\text { at the top } \\
(\mathrm{cm})\end{array}$} & \multicolumn{2}{|c|}{ Roots } & \multirow[b]{2}{*}{$\begin{array}{l}\text { Number } \\
\text { of side } \\
\text { roots with } \\
\emptyset \geq 0.5 \mathrm{~cm}\end{array}$} & \multirow[b]{2}{*}{$\begin{array}{l}\text { Root } \\
\text { yield } \\
\text { (t/ha) }\end{array}$} \\
\hline & & & & & & & & $\begin{array}{l}\text { Diameter } \\
\text { at the base } \\
\text { (cm) }\end{array}$ & $\begin{array}{l}\text { Side } \\
\text { roots } \\
\text { number } \\
\text { (n/plant) }\end{array}$ & & \\
\hline $2014-2015$ & S1 & $\begin{array}{l}\text { COR } \\
\text { MON } \\
\text { COR } \\
\text { MON } \\
\text { COR } \\
\text { MON }\end{array}$ & $\begin{array}{l}340 \pm 43 \\
334 \pm 57 \\
407 \pm 93 \\
434 \pm 39 \\
83 \pm 13 \\
95 \pm 10\end{array}$ & $\begin{array}{l}16 \pm 3.2 \\
21 \pm 3.5 \\
28 \pm 3.5 \\
39 \pm 5.3 \\
31 \pm 2.0 \\
43 \pm 3.5\end{array}$ & $\begin{array}{c}55 \pm 2.0 \\
58 \pm 4.9 \\
58 \pm 3.0 \\
62 \pm 3.6 \\
2-8^{a} \\
2-8^{a}\end{array}$ & $\begin{array}{c}84 \pm 6.4 \\
101 \pm 10.5 \\
165 \pm 40.2 \\
155 \pm 37.8 \\
274 \pm 28.2 \\
299 \pm 33.0\end{array}$ & $\begin{array}{l}2.8 \pm 0.1 \\
2.7 \pm 0.2 \\
4.0 \pm 0.2 \\
3.7 \pm 0.5 \\
3.8 \pm 0.2 \\
4.0 \pm 0.3\end{array}$ & $\begin{array}{l}1.9 \pm 0.2 \\
2.0 \pm 0.3 \\
2.9 \pm 0.4 \\
3.1 \pm 0.4 \\
2.8 \pm 0.2 \\
3.2 \pm 0.3\end{array}$ & $\begin{array}{c}3.0 \pm 0.4 \\
2.7 \pm 0.6 \\
5.0 \pm 1.4 \\
3.0 \pm 1.4 \\
15.1 \pm 2.4 \\
14.0 \pm 1.9\end{array}$ & $\begin{array}{c}- \\
- \\
- \\
- \\
6.5 \pm 0.6 \\
5.0 \pm 0.8\end{array}$ & $\begin{array}{c}3.3 \pm 0.3 \\
4.0 \pm 0.4 \\
6.5 \pm 1.6 \\
6.2 \pm 1.5 \\
10.9 \pm 1.1 \\
12.0 \pm 1.3\end{array}$ \\
\hline 2015-2016 & S1 & $\begin{array}{l}\text { COR } \\
\text { MON } \\
\text { COR } \\
\text { MON } \\
\text { COR } \\
\text { MON }\end{array}$ & $\begin{array}{l}795 \pm 69 \\
908 \pm 97 \\
560 \pm 77 \\
647 \pm 87 \\
222 \pm 24 \\
350 \pm 25\end{array}$ & $\begin{array}{c}55 \pm 8.3 \\
82 \pm 9.8 \\
79 \pm 19.2 \\
99 \pm 21.9 \\
55 \pm 23.4 \\
78 \pm 14.7\end{array}$ & $\begin{array}{c}63 \pm 2.3 \\
59 \pm 2.2 \\
62 \pm 4.2 \\
65 \pm 5.3 \\
3-10^{\mathrm{a}} \\
3-10^{\mathrm{a}}\end{array}$ & $\begin{array}{l}464 \pm 51.6 \\
499 \pm 34.6 \\
521 \pm 89.2 \\
601 \pm 67.4 \\
606 \pm 74.1 \\
611 \pm 69.3\end{array}$ & $\begin{array}{l}6.1 \pm 0.7 \\
7.0 \pm 0.3 \\
6.7 \pm 0.6 \\
6.5 \pm 0.1 \\
7.0 \pm 0.6 \\
7.5 \pm 0.4\end{array}$ & $\begin{array}{l}3.7 \pm 0.6 \\
4.2 \pm 0.5 \\
3.5 \pm 0.4 \\
4.7 \pm 0.3 \\
3.9 \pm 0.7 \\
5.2 \pm 0.2\end{array}$ & $\begin{array}{c}6.3 \pm 2.0 \\
8.3 \pm 0.9 \\
16.7 \pm 1.5 \\
10.3 \pm 3.6 \\
17.4 \pm 1.2 \\
15.0 \pm 1.2\end{array}$ & $\begin{array}{l}5.0 \pm 0.5 \\
4.0 \pm 0.6 \\
5.9 \pm 0.9 \\
5.0 \pm 1.4 \\
6.7 \pm 1.2 \\
7.0 \pm 0.7\end{array}$ & $\begin{array}{l}13.9 \pm 4.9 \\
20.0 \pm 1.4 \\
15.6 \pm 6.2 \\
24.0 \pm 5.2 \\
24.2 \pm 3.6 \\
24.4 \pm 2.8\end{array}$ \\
\hline
\end{tabular}

F probability

\begin{tabular}{|c|c|c|c|c|c|c|c|c|c|}
\hline Accession (A) & n.s. & $* *$ & n.s. & n.s & n.s. & $*$ & $*$ & n.s. & n.s \\
\hline Stage (S) & $* * *$ & $* * *$ & $*$ & $* * *$ & $* * *$ & $* * *$ & $* * *$ & n.s. & $* * *$ \\
\hline$A \times S$ & n.s & n.s. & n.s. & n.s. & $* *$ & $*$ & n.s. & n.s & n.s. \\
\hline
\end{tabular}

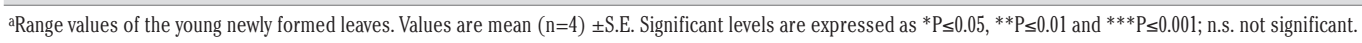


the foliage was almost completely dry (Table 2). The dry leaves represented 12,16 , and $99 \%$ of total leaves at S1, S2 and S3 stages, respectively, during 2014 and 43, 49, 98\% of total leaves during 2015. Depending on air temperature and rainfall, the plant regulates the leaf development by anticipating or postponing the drying of the mature and old leaves (S2 stage) and the simultaneous formation of the new ones. In both growing cycles analysed at stage S3 (root harvesting), the horseradish plants presented the old leaves completely dry and several new young leaves wrapped in a rosette, that weighed 14 and $42 \mathrm{~g}$ in January 2015 and 2016, respectively (average values between accessions) (Table 2). To our knowledge, no data is available in literature referring to plant growth and leaf area development other than those by De Maria et al. (2018), who proposed non-destructive linear models to accurately estimate the leaf area of horseradish throughout the entire crop cycle. De Maria et al. (2016) also stressed the importance of the leaves due to the richness of phytochemicals; indeed the authors reported that the rosette leaves contain a great GLS concentration up to ten-fold higher than roots during the harvesting period, and fivefold higher later, when the foliage is fully developed. The same authors investigating relationships between tissues (leaves and root) and GLS suggested a co-regulation of their biosynthesis or degradation depending on plant tissues. Horseradish roots as well as leaves have been used in the past for condiments and medicinal purposes, but today only the roots are ground and used for fresh market and manufacturing of various condiment products (Walters and Wahle, 2010). On account of the great leaf biomass production that could provide substantial quantities of health-affecting compounds, also the leaves of horseradish should be more valorised and utilised for fresh consumption as well as also in pharmaceutical and industrial sectors, e.g. as an additive for functional foods or food supplements.

Analysing the whole root system, we found that root FW and diameter at the top did not statistically differ between accessions, while, as expected, they differed comparing the stages of development $(\mathrm{P} \leq 0.001)$. The root $\mathrm{FW}$ and the diameter at the top gradually increased throughout the growing cycles passing, on average, from $93 \mathrm{~g}$ and $2.7 \mathrm{~cm}$ to $610 \mathrm{~g}$ and $7.3 \mathrm{~cm}$ (Table 2). The root diameter at the base, instead, resulted statistically different between accessions $(P \leq 0.05)$, stages $(P \leq 0.001)$ and their interaction $(\mathrm{P} \leq 0.05)$. Due to the different ratio between root diameter at the top and at the base (data not shown), COR had an almost cylindrical shape while the root of MON tends to have a frustoconical shape. Both accessions resulted in a ruled texture with a white pulp in COR accession tending to yellow colours in MON. Shape, colour and wrinkle, together with the weight of the main root are the most important traits for both industrial processing and fresh market (Perlaki and Djurovka, 2009). During the growth cycles, the species produced a number of lateral roots differing in diameters and length along the main root. In our case, the lateral roots increased over time from 2.8 per plant up to 16 in two-year old roots, with $39 \%$ and $47 \%$ of the roots with a diameter greater than $0.5 \mathrm{~cm}$ in COR accession and MON, respectively, mostly concentrated in the upper third part of the main root. The side roots can be utilised for fresh market, but are generally used as stock of root cuttings for planting the following season (Walters and Wahle, 2010). Under our experimental conditions (Mediterranean rain fed environment), the two accessions, relying only on an annual rainfall of $670 \mathrm{~mm}$, produced about $11.5 \mathrm{t} \mathrm{ha}^{-1}$ and $24.3 \mathrm{t} \mathrm{ha}^{-1}$ of roots (including the main root with the crown and side roots with diameters $\geq 0.5 \mathrm{~cm}$ ) of oneand two-year old plantations, respectively (Table 2). Horseradish can be produced in an annual and perennial production system; most of the big producers (such as in Illinois, which is the most concentrated area of horseradish production in the world) prefer the annual system because the perennial, in which horseradish may stay productive for 10 to 20 years or more, requires greater field management (Walters and Wahle, 2010). Over the threeyear study, Perlaki and Djurovka (2009) reported increases of root yields and main root weight depending on the amount and kind of fertiliser used. Large variations in root yield were also found depending on accessions; particularly, Agneta et al. (2014b) comparing six horseradish accessions cultivated in temperate Mediterranean area found total root yield varying from 120 up to 1070 g plant $^{-1}$; Rivelli et al. (2016b) testing two of the six above-mentioned horseradish accessions (ST here referred as $\mathrm{COR}$ and $\mathrm{MON}$ ) grown in a warm to temperate environment and supplemental irrigation reported that root $\mathrm{FW}$ was double in COR in comparison to MON (925 vs 476 g/plant, respectively) with diameters larger than 40\%; while Rivelli et al. (2016a) reported increases of both yield and glucosinulates concentration in response to fertilisation and harvesting. Considering the average values between accessions, close relationships were found relating the number of leaves both with root fresh weight $\left(\mathrm{r}^{2}=0.88 ; \mathrm{P} \leq 0.01\right)$ and diameter at the top $\left(\mathrm{r}^{2}=0.82 ; \mathrm{P} \leq 0.01\right)$ (Figure 4). On the other hand, it is well known that the development of the aerial part of the plant (particularly for rhizomatous plants such as horseradish) can certainly influence the enlargement of the root system and vice versa. In addition, Rivelli et al. (2016b) found that total GLS in plants is closely related to root fresh weight and diameter. Moreover, De Maria et al. (2016) considering the variations of glucosinulates in leaves and roots, found that almost all of the nine individual GLS considered were correlated with each other, suggesting a co-regulation of their biosynthesis or degradation depending on tissues and organs of the plant. According to USDA guidelines, horseradish is commercialised in three grates based on root diameter and length; while $\mathrm{Ku}$ et al. (2015) highlighted that higher grates display better quality, with higher sinigrin and allyl-isothiocyanate contents.

\section{Conclusions}

Overall, the results suggest the importance to know the physiology and agronomic characteristics of horseradish to purposefully apply agronomic practices and strategies to maximize benefits for production and root quality and to modulate the health-promoting compounds in plants according to the specific use or application, i.e., fresh market, pharmaceutical and food industries.

Because of the differences in the morphometric and agronomic traits among the accessions that we cultivate nowadays, as found in previous studies, we stress the importance to characterise with an agronomic approach the available horseradish germplasm, which we still have in the Basilicata region (Southern Italy), as well as in many other parts of the world, to identify the genotypes with high-value bioactive compounds and the highest yield performances and to preserve the plant genetic resources against genetic erosion.

\section{References}

Agneta R, Lelario F, De Maria S, Möllers C, Bufo SA, Rivelli AR, 2014a. Glucosinolate profile and distribution among plant tis- 
sues and phenological stages of field-grown horseradish. Phytochem. 106:178-87.

Agneta R, Möllers C, De Maria S, Rivelli AR, 2014b. Evaluation of root yield traits and glucosinolate concentration of different Armoracia rusticana accessions in Basilicata region (southern Italy). Sci. Hort. 170:249-55.

Agneta R, Möllers C, Rivelli AR, 2013. Horseradish (Armoracia rusticana), a neglected medical and condiment species with a relevant glucosinolate profile: a review. Genet. Resour. Crop Evol. 60:1923-43.

Bell L, Oloyede O, Lignou S, Wagstaff C, Methven L, 2018. Taste and flavour perceptions of glucosinulates, isothiocyanates, and related compounds. Mol. Nutr. Food Res. 62:1-13.

Björkman M, Klingen I, Birch ANE, Bones AM, Bruce TJA, Johansen TJ, Meadow R, Mølmann J, Seljảsen R, Smart LE, Stewart D, 2011. Phytochemicals of Brassicaceae in plant protection and human health - Influences of climate, environment and agronomic practice. Phytochem. 72:538-56.

Calabrone L, Larocca M, Manzocco S, Martelli G, Rossano R, 2015. Total phenols and flavonoids content, antioxidant capacity and lipase inhibition of root and leaf horseradish (Armoracia rusticana) extracts. Food Nutr Sci. 6:64-74.

Chowański S, Chudzińska E, Lelario F, Ventrella E, Marciniak P, Miądowicz-Kobielska M, Spochacz M, Szymczak M, Scrano L, Bufo SA, Adamski Z, 2018. Insecticidal properties of Solanum nigrum and Armoracia rusticana extracts on reproduction and development of Drosophila melanogaster. Ecotox. Env. Safety. 162:454-63.

Ciska E, Horbowicz M, Rogowska M, Kosson R, Drabińska N, Honke J, 2017. Evaluation of seasonal variations in the glucosinolate content in leaves and roots of four European horseradish (Armoracia rusticana) landraces. Pol. J. Food Nutr. Sci. 67:301-8.

Courter JW, Rhodes AM, 1969. Historical notes on horseradish. Econ. Bot. 23:156-64.

De Maria S, Agneta R, Lelario F, Möllers C, Rivelli AR, 2016. Influence of nitrogen and sulphur fertilisation on glucosinolate content and composition of horseradish plants harvested at different developmental stages. Acta Physiol. Plant. 38:1-12.

De Maria S, Rita A, Trotta V, Rivelli AR, 2018. Assessment of a non-destructive method to estimate the leaf area of Armoracia rusticana. Acta Physiol. Plant. 40:1-7.

Filipović V, Popović V, Aćimović M, 2015. Organic production of horseradish (Armoracia rustivcana Gaertn., Mey., Scherb.) in Serbian Metropolitan Regions. Proc. Econ. Finan. 22:105-13.

Guarrera PM, Savo V, 2016. Wild food plants used in traditional vegetable mixtures in Italy. J. Ethnopharm. 185:202-34.

Kroener E, Buettner A, 2018. Sensory-analytical comparison of the aroma of different horseradish varieties (Armoracia rusticana). Front Chem. 6:1-11.

Ku KM, Jeffery EH, Juvik JA, Kushad MM, 2015. Correlation of quinone reductase activity and allyl isothiocyanate formation among different genotypes and grades of horseradish roots. J. Agric. Food Chem. 63:2947-55.

Martínez-Ballesta MC, Moreno DA, Carvajal M, 2013. The physiological importance of glucosinulates on plant response to abiotic stress in Brassica. Int. J. Mol. Sci. 14:11607-25.

Nguyen NM, Gonda S, Vasas G, 2013. A review on the phytochemical composition and potential medicinal uses of horseradish (Armoracia rusticana) root. Food Rev. Intern. 29:261-75.

Papp N, Gonda S, Kiss-Szikszai A, Plaszkó T, 2018. Ethnobotanical and ethnopharmacological data of Armoracia rusticana P. Gaetner, B Meyer et Scherb. In Ungary and Romania: a case study. Genet. Resour. Crop Evol. 65:1893905.

Perlaki Z, Djurovka M, 2009. Horseradish root yield depending on organic and mineral fertilisers. Contemporary Agriculture. 58:106-11.

Petrríková K, Urbánková J, Faberová I, 1998. Descriptor list. Genus Armoracia P. Gaertn., B. Mey. et Scherb. Genetic Resources 70, 11 pp. VURV Praha, MZLU ZF Lednice na Moravě.

Petrović S, Drobac M, Ušjak L, Filipović V, Milenković M, 2017. Volatiles of roots of wild-growing and cultivated Armoracia macrocarpa and their antimicrobial activity, in comparison to horseradish, A. Rusticana. Indust. Crops Prod. 109:398-403.

Porra RJ, Thompson WA, Kriedemann PE, 1989. Determination of accurate extinction coefficients and simultaneous equations for assaying chlorophylls a and b extracted with four different solvents: verification of the concentration of chlorophyll standards by atomic absorption spectroscopy. Biochim. Biophys. Acta. 975:384-94.

Rivelli AR, Agneta R, Möllers C, De Maria S, 2016a. Evaluating strategies to improve glucosinolate concentration and root yield of field-grown horseradish in a Mediterranean environment: preliminary results. Ital. J. Agron. 11:65-8.

Rivelli AR, Caruso M, De Maria S, Galgano F, 2017. Vitamin C content in leaves and roots of horseradish (Armoracia rusticana): seasonal variation in fresh tissues and retention as affected by storage conditions. Emir. J. Food Agr. 29:799-806.

Rivelli AR, Lelario F, Agneta R, Möllers C, De Maria S, 2016 b. Variation of glucosinolates concentration and root growth of horseradish as affected by nitrogen and sulphur supply. Plant Soil Environ. 62:307-13.

Saladino F, Bordin K, Bittencourt L, Frnández Franzón M, Maňes J, Meca G, 2016. Antimicrobial activity of the glucosinulates. In: Mérillon JM, Ramawat K (Eds.), Glucosinulates. Reference Series in Phytochemistry. Springer, Cham.

Sampliner D, Miller A, 2009. Ethnobotany of horseradish (Armoracia rusticana, Brassicaceae) and its wild relatives (Armoracia spp.): reproductive biology and local uses in their native ranges. Econ. Bot. 63:303-13.

Sarli G, De Lisi A, Agneta R, Grieco S, Ierardi G, Montemurro F, Negro D, Montesano V, 2012. Collecting horseradish (Armoracia rusticana, Brassicaceae): local uses and morphological characterisation in Basilicata (Southern Italy). Genet. Resour. Crop Evol. 59:889-99.

Sayeed MA, Bracci M, Lazzarini R, Tomasetti M, Amati M, Lucarini G, Di Primio R, Santarelli L, 2017. Use of potential dietary phytochemicals to target miRNA: Promising option for breast cancer prevention and treatment? J. Funct. Foods. 28:177-93.

Shehata AM, Mulwa RMS, Babadoost M, Uchanski M, Norton MA, Skirvin R, Walters SA. 2009. Horseradish: Botany, Horticulture, Breeding. In: Janick J. (Ed.), Horticultural Reviews. John Wiley and Sons Inc., Hoboken, NJ, USA, 35:221-61.

Stillo P, Icka P, Damo R, 2018. Armoracia rusticana Gaertn., Mey. \& Scherb. A neglected multiuseful species. BSHN (UT). 26:312-22.

UPOV International Union for the Protection of New Varieties of Plants, 2001. Guidelines for the conduct of tests for distinctness, uniformity and stability. Horseradish (Armoracia rusticana Gaertn, Mey. \& Scherb.). TG/191/2. Geneva.

Veitch NC, 2004. Horseradish peroxidase: A modern view of a classic enzyme. Phytochem. 65:249-59. 
Vig AP, Rampal G, Thind TS, Arora S, 2009. Bio-protective effects of glucosinolates - A review. Food Sci. Technol. 42:1561-72.

Walters SA, Wahle EA, 2010. Horseradish Production in Illinois. Hort. Tecn. 20:267-76.

Wedelsbäck Bladh K, 2014. Biodiversity in Nordic Horseradish (Armoracia rusticana). Studies with respect to conservation and utilisation. PhD Doctoral thesis n. 2014:97, Swedish University of Agricultural Sciences, Alnarp, Sweden.

Wedelsbäck Bladh K, Olsson KM, 2011. Introduction and use of horseradish (Armoracia rusticana) as food and medicine from antiquity to the present: emphasis on the Nordic countries. J. Herbs Spices Med. Plants. 17:197-213. 